\title{
Historicizing Ethno-Religious and Political Conflicts in West Africa: The Malian Case
}

\author{
Saliou Dione ${ }^{1}$, Bakaye Togola ${ }^{1}$ \\ ${ }^{1}$ African and Postcolonial Studies \\ ${ }^{I}$ Department of Anglophone Studies \\ ${ }^{I}$ Cheikh Anta Diop University of Dakar (Senegal) \\ salioudione@hotmail.com
}

\begin{abstract}
This article historicizes ethno-religious and political conflicts in West Africa with Mali as a case in point. It looks at how foreign and donors' conditioned aid can pose a threat to peaceful existence and survival of West African States. In fact, Mali has since its independence been beset by an extraordinary heavy burden of conflicts. It is either suffering from rebellions or political instability. Added to this, are the current religous problems which are undermining its territorial unity as a result of rising questions and distrust between northern and southern communities. This paper analyzes the reasons for the central authorities' opposition to the northern population, namely the Tuareg and Arabs, on the one hand, and the States to the military, on the other hand. It also brings to light the politically, religiously, and militarily 'divisive' roles of external stakeholder such as the naighboring and Gulf countries, France and the international community as it examines the couses and impacts of the political, social, and religious fragmentations, using a historical perspective, and provides for endogenous and exogenous solutions.
\end{abstract}

Keywords: mali; conflict; peace; north; history; religion; terrorism.

\section{Introduction}

Post-colonial Mali has been faced with ethnic tensions which are among the major legacies of colonialism. At the Berlin congress held in 1885, the colonial powers such as Germany, England, France, Portugal, Italy, etc., partitioned Africa into territorial units. Consequently, kingdoms, States, and communities were arbitrarily divided, unrelated areas and people were just as arbitrarily joined together. ${ }^{1}$ This part of Africa's history has arisen interest among many African and non-African scholars who are interested in African politics. Many of them have blamed the ethnic divisions and rivalry amongst the nations in Africa on the arbitrary boundaries and cultural differences that were engendered and imposed upon the local populations by the former colonial powers. In fact, the West African country gained its independence from France on September 22, 1960. This came after a short-lived union known as the 'The Mali Federation', proclaimed a few months earlier and linking the French colonies of Senegal and the Sudanese Republic or French Sudan for a period of only two months in $1960^{2}$. Indeed, its name derives from an Empire that covered parts of present-day Mali from the 13th to the 16th centuries. Nestled deep in the interior of West Africa, the country is surrounded by Algeria in the North, Niger to the East, Burkina Faso and Cote d'Ivoire at the South, Guinea to the South-West, and Senegal and Mauritania to the West.

\footnotetext{
${ }^{1}$ Monica Juma (2006), Compendium of Key Document Relating to Peace and Security in Africa, South Africa, Pretoria University Law Press (PULP), p. 390.

${ }^{2}$ Thomas Hodgkin \& Ruth Schacter Morgenthau (1964). “Mali”. In James Scott Coleman (ed). Political Parties and National Integration in Tropical Africa. Berkley, CA: University of California Press. P..216-258, p. 243.
} 


\section{Review of Literature}

Since the end of the colonial rule two groups have been contesting the State's authority and constitutional order, i.e., putschists and insurgent groups. A difference in perception between the people of the North and the authorities resulted in people dealing with rebellions. Some historically rooted distrusts also led to four Tuareg and Arab uprisings following independence, especially in 1963, 1991, 2006, and 2012, and three military coups. The problem of rebellion and ethnic division in the Northern part of the country is not then something new. It traces its origin back to the Western invasion into the country when the colonizers faced harshresistance and decided to pit the ethnic groups against each other. So, understanding the current Malian crisis requires interrogating history so as to grasp their related political, economic, and religious factors and avoid falling into the trap of what Nigerian writer Chimamanda Ngozi Adichie calls 'the danger of a single story', to refer the Western narration of this part of West African (hi)story. Indeed, many scholars have traced out the Mali's rebellions and military coups to the centralized management of the State by French colonization and corruption. Gregory Chauzal et $a l .(2015)^{3}$ explore what they think to the most prominent root causes and the global influences that account for the 2012 crises by addressing the local issues and international dynamics that have contributed in undermining peace and security in the country. Charles Gremont $(2010)^{4}$ traces the origins of the rebellions and ethnic problems back to European colonial invasion, from the Berlin conference (1884$1885)$ to the independence year (1960) by highlighting, looking critically at marginalization of the white-skinned community until 1993 as well as analyzing the relationships and opposition between the central government and the Tuaregand Arabs. As for Moussa Konate $(1990)^{5}$, he underscores the military coups are the result of a rampant culture of corruption, bribery, and embezzlement in the country. Serge Daniel $(2014)^{6}$ both explains the motivations of the Islamists and terrorists, and their sources of funding, and denounces poverty in the conflict-stricken areas where the religious extremists and charity organizations operate and draw links with the local populations. Following the same line of ideas, Robin-Edward Poulton and $a l .(1998)^{7}$ account for the failures of the different peace agreements as the root causes of past conflicts and suggested sustainable solutions. But these scholars have failed to discuss the extent to which external assistance has contributed to the multiple military coups, continuous rebellions, and radicalization of many local populations.

Armed conflicts can be either national or/and international. Those of Mali were national until international forces got involved in 2013, thus turning them into asymmetric warfare in which the belligerents' relatively military power, strategy, and tactics differs considerably. They are characterized by the use of guerilla, surprised attacks in the form of rezzou, with civilians as human shields and ambush. There are also some cases of open conflicts, though scarce, which are face-to-face combats. The continuous rebellions in the northern part since the country's independence and the diverse donor-countries-backed

\footnotetext{
${ }^{3}$ Gregory Chauzal and Thibault van Damme (2015), The Roots of Mali's Conflicts: Moving Beyond the 2012 Crisis, CRU Report, Clingendal.

${ }^{4}$ Charles Gremont (2010), Touaregs et Arabes dans les forces armées coloniales et maliennes: Une histoire en trempe d'œil, Paris, IFRI Programme Afrique Sub-Saharienne.

${ }^{5}$ Moussa Konate (1990), Mali: Ils ont assassiné l'espoir, Paris, l'Harmattan.

${ }^{6}$ Serge Daniel (2014), Les Mafias au Mali: Trafic et terrorisme au Sahel, Paris, Descartes et Cie.

7 Robin-Edward Poulton andIbrahima ag Youssouf (1998), A Peace of Timbuktu: Democratic Governance, Development and African Peacemaking, Geneva, UNIDIR.
} 
military interventions aimed at ousting the presidents from the power have led many people to wonder whether the seemingly foreign aids are not a source of instability and tension instead of peace. How can then a country that is often cited as a model of democracy be always shaken by rebellions and everlasting institutional crises? What are the [underlying] motivations of the different protagonists and the negative consequences of those troubles in Mali's socio-economic development? How can Malian population resolve the internal conflicts that have been endangering the social and cultural collaboration for more than half a century?

Therefore, it would be relevant to look at the possible dangers that foreign aid and donors can pose to the country's peaceful existence and survival by exploring the root causes of the fragmentation that are both political and social. Terrorism being a reality everywhere in the world, focusing on a historical and sociological approach, embedded with an Afrocentric and postcolonial perspective, this article seeks to give an account of the ethno-religious and political conflicts in Mali and the challenges at stake so as to reach sustainable peace with endogenous solutions and international coordination in a neo-colonialism and globalism context marked by 'economic wars' and new political dynamisms. It also highlights the roles of external stakeholders such as the neighboring and Gulf countries for their political involvement and France and the international community for their military part.

\section{Discussion \\ 3.1 Internal Political Conflict as Source of Fragmentation and Rebellion in Post - colonial Mali}

A group of young soldiers, who experienced Western democracy and compared their country to some other neighboring ones, decided to overthrow the Modibo Keita-led first Malian regime on November 19, 1968 without contestation and bloodshed. In analyzing the political situation of the world and the reason for that military coup, one could argue that there was an invisible hand behind that military act. ${ }^{8}$ Because upon arrested, he was asked to get rid of the socialist view and some of his close friends, which he vetoed on the ground. Modibo Keita, the president died on May 16, 1977 while in detention at the military barrack of Djicoroni Para under circumstances which have still remained unknown. His death triggered demonstrations by associations of teachers and students which were violently repressed by the junta in their attempt to silence the organizers who were calling for a return to civilian regime. To reinforce their power, the junta embarked on a politics of control of knowledge and means of communication, in which they took guns and demanded absolute obedience. They ruled by the Barrel of a Gun, ${ }^{9}$ to paraphrase Ruth $(1970)^{10}$. However, the international community and the human right associations did not cross their hands; they pressurized the military regime to organize democratic elections as soon as possible. To meet the demand of NGOs and seemingly development partners and to continue benefitting from foreign aid, the junta transformed their Committee into a political party, the "Democratic Union of the Malian people" (UDPM) and called for single-party election. The election did

\footnotetext{
${ }^{8}$ The military coup has happened at the period of the Cold war and when the western countries were promoting their liberal democracy.

${ }^{9}$ Ruth First (1970), The Barrel of a Gun: Political Power in Africa and the Coup d'Etat, London, Penguin.

${ }^{10}$ Idem.
} 
not cool down the situation since Malian students took to the streets again to ask for the establishment of a democratic regime and multi-party elections $\backslash$.

In fact, the state building has started ceasing because, as George Burdeau has argued, "The State is formed when the power has not its roots in a person but in an institution." 11 This accounts for loss of power of the president who emerged from the putsch, President Moussa Traore after his public and military support started waning. He mistakenly interpreted the mobilizations he saw when touring the different parts of the country. He mistook the tam-tam, the singing and dancing of hunters and women for as a sign of popularity and declared in 1988 "my people have understood me." 12 In doing so, he failed to take into account that Malians liked distraction and would not have refused to dance even though they were suffering. The government also forgot that "the world is like a mask dancing. If you want to see it well you do not stand in one place"13 aimed at describing the need for change. The call coincided with the shift in world politics in the West with the end of the Cold War and the fall of the Berlin Wall, engendering a drastic reduction in military and financial support destined to some African 'brutal' dictators.

In addition to failing to improve Malian people's living conditions, the oppression of political opponents, embezzlement, corruption, bribery, among other vices were used as motto by Moussa Traore-led military regime. Thus, the funds allocated to help drought-stricken people, thousands of whom were dead, particularly among the pastoral communities in the Northern regions, were embezzled by the members of his Committee. The money was rather used to build their houses in Bamako, which some people ironically referred to as the 'Palaces of Drought,' marry new wives and go out with young girls for weekends. ${ }^{14}$ To better consolidate their power, some of the country's most valuable intellectuals were forced into exile or killed. It is in this context that Robert Lee $(1970)^{15}$ has argued that people have noticed that 'The emerging 'Malian State,' having successfully gotten rid of farmer Jones, now has to reckon with Napoleon and his $\operatorname{dogs}$," 16 to mean that in Mali a group of oppressors was replacing another one more 'odious.'

In referring more and more to some neighboring countries and to the confiscation of power by some 'selfish' people who only think of their pockets and their families, the Malian people took to the street again in January 1991 to claim democracy, multi-party elections, and good governance. The situation was exacerbated by corruption and the politics of impunity which those in power benefitted from. The president's close families (his family and his family-in-law) were protected by the government despite their involvement in financial scandals. ${ }^{17}$ On March $26^{\text {th }} 1991$, after many days of popular demonstrations, a group of soldiers led by Amadou Toumani Toure decided to overthrow the regime under the pretext of the quest for democracy and multiparty elections.

However, at the very beginning of the democratization process under President Alpha Oumar Konare was marred by social movements, economic difficulties, political instability, and rumours of electoral fraud, election boycott and corruption amongst the ruling party ADEMA. It became almost impossible for people to access to the public services without

\footnotetext{
${ }^{11}$ Georges Burdeau (1980), «L'Etat», in Traité de Science Politique, Paris, LGDJ, p. 183.

${ }^{12}$ Mémoire d'un continent, RFI, recorded in Bamako in October 1988.

${ }^{13}$ Chinua Achebe (1964), Arrow of God, Heinemann, UK, p. 46.

${ }^{14}$ Konate Moussa (1990), Mali Ils ont assassiné l'espoir, Paris, L'Harmattan, p. 64.

${ }^{15}$ Robert Lee (1970), Orwell's Fiction, Notre Dame, IN: University of Notre Dame Press.

${ }^{16}$ Robert Lee (1970), Orwell's Fiction, op. cit., p. 12.

${ }^{17}$ Pierre Péan (1988), L'Argent Noir: Corruption et sous-développement, Paris, Fayard, pp. 232-233.
} 
paying bribes. The ensuing personalized rule and bad governance led not only to the politicization of the army and security agencies, but also to the fragility of the State. The political class appeared to be doing little more than enriching themselves at the expense of the middle-class citizens. The representation by Chinua Achebe $(1966)^{18}$, referring to some members of opposition parties as "people in the rain with those in power for a long time, the leaders have gone into the house to seek shelter from the rain and have persuaded the people to desist from arguing else they subvert and bring down the whole house,"19 applies to the Malian context. The leaders' lack of vision for the country's future led to forms of politics based on diversions, lies, manipulation, bribery, violence, and elections rigging. Few development policies were initiated for the populations who were being stricken by poverty, hopelessness, who had the feeling of being exploited and of having been forgotten by the ruling elites, whose private savings were bursting European and North American's bank vaults.

Moreover, a 'theatre' for public opinion management was put in place in Mali. The initiative aimed at dismissing those involved in corruption, illicit embezzlement, nepotism, and land speculation cases. But the initiative did not last long. Because no sooner had they been dismissed than they were re-appointed to other positions as ambassadors or Chief Executive Officers of State-owned businesses. These practices became enshrined in Mali's daily life and they were normalized across the country. Scarcely did the judicial system intervene to deal with cases of corruption and power abuse involving political leaders from the ruling party while the ordinary Malian citizen was easily sent to jail for whatever offence they made.. At the same time, the country's army felt humiliated after their defeat to the Tuare $^{20}$ and drug traffickers because of lack of weapons and military equipment to protect themselves and their countrymen. Having disapproved of the deterioration of the democratic system by the regimes and the rampaging of corruption, unemployment rate, a group of NonCommissioned Officers (NCO's) seized the power on the night of March 21 to 22, 2012 under the leadership of Amadou Haya Sanogo. The latter had only the rank of Captain in an army where there were many more senior officers. Despite that, he became the leader of the military junta.The country's post-democratic management further deepened Malian people's dependence on foreign and neighboring countries' assistance. That situation also gave way to political interferences as evidenced by the roles of Algeria and Libya in the conflict in northern Mali that burst out several times. In addition to that was the inability of Malian authorities to control and regulate those exogenous influences. In the absence of positive attitude towards their plight from the government by way of investment and provision of infrastructure that make life worth living, the Tuareg and Arabs continued to nurture a feeling of citizens who were hopeless, frustrated and marginalized. These sentiments then made it easy for the militant groups and other criminal organizations to settle in the area and exploit the conditions of abject poverty in the region.

\footnotetext{
${ }^{18}$ Chinua Achebe (1966), A Man of the People, London, Heinemann, p. 37.

${ }^{19}$ Chinua Achebe (1966), op. cit., p. 37.

${ }^{20}$ Tuareg are also called Kel-Tamasheq which is used to name all those (white and black) who speak the Tamasheq language. The Tuareg group is composed of three main tributes: the Ouillimiden, the Ifoghas and the Kel-Tadmakat. Ifoghas belongs to the Adrar des Ifoghas. The Ouillimiden was the most powerful Tuareg tribute before the western invasion.See Mohamed Tiessa-Farma Maïga (1997), Le Mali: De la sècheresse a la rébellion nomade. Chronique et analyse d'un double phénomène du contre développement en Afrique sahélienne, Paris, France, L'Harmattan, pp. 104-105.
} 
As a consequence, and despite their positive effect on northern populations, the real intentions of some NGOs were often questioned. ${ }^{21}$ One of the most revealing evidences of such alternatives to public systems of provision was the Madrasas or Quranicschools that became rapidly popular in Mali. In the late 1980s, 25 percent of Malian primary-age school children were attending these types of institution. ${ }^{22}$ Offering free education, the Madrasasenabled lower-class people to send their children to school, as it presented an alternative to the ineffective public education system and private schooling networks. But it also meant that the education was provided mostly in Arabic. That took place in an area where colonial schools were not the norm, except for selected traditional leaders' kids, and the use of the French language was not common ${ }^{23}$. The new learning system then contributed in widening the educational gap between Mali's northern and southern populations. Those Quranic schools built by wahhabists taught the $d a$ 'wa and their students are easy preys for the terrorists. In most of the markezes and Madrasas, the Wahhabists practiced martial artsas a way ofgetting ready for jihad.Before the arrival of the foreign extremists, they went round families and villages to teach them what they deemed to be the real Islamic practices, thus hiding behind religion to embark the local population on an indoctrination process.

However, regional political and security interference in the Sahel was a determining factor in the 2012 crisis. In feeding rebellions through political support, economic assistance, and military supply, or in fostering internal political divisions within the Nomad communities, foreign countries bear significant responsibility for insecurity in the Sahel. Over the years, the north of Mali has become an area of strategic, economic, and security interest for several regional powers, especially the Arab countries (Libya and Algeria and, to a lesser extent, Morocco) where lived the same ethnic groups, on the one hand and France and its European Union partners, the United States of America, on the other hand. Even of Moroccan influence of in the area cannot be downplayed ${ }^{24}$, Libya and Algeria have been the most active stakeholders in the region over the past 30 years. And the conflict in Libya, which resulted in the death of Libyan leader Muammar Gaddafi, highly contributed in accelerating that of Mali.

\footnotetext{
21 The Islamic NGOs combined their charity activities with some degree of $d a$ 'wa (preaching). The AfroArabian Cultural Institute (sponsored by Saudi Arabia), the World Association for the Islamic Call (Libya), Al Mountada (Saudi Arabia), the African Muslims Agency (Koweit), Islamic Relief (UK), the Hamdallaye Islamic Cultural Center (United Arab Emirates), the Red Crescent or Charity Qatar then played a big role in assisting Malian populations. See: Allemandou Ségolène (23 January 2013), "Is Qatar fuelling the crisis in North Mali?," France24, or International Crisis Group, Islamist terrorism in the Sahel: Fact or Fiction, Africa Report no. 92, March 2005, p. 16.

${ }^{22}$ According to Bandiougou Gakou, former ambassador of Mali to the Middle-East (Iran), the Madrasas helped the spread of Salafism in Mali by teaching the Wahhabi doctrine. In 2000 there were 520 madrasas in Mali (13 percent of the Malian pupils and approximately 100,000 young students). Fousseyni Maiga (6 March 2013), «Aux sources de la crise Malienne,» Courrier International.

${ }^{23}$ In Mali in 2015, only 17 percent of the population were francophone: Organisation Internationale de la Francophonie, La langue française dans le monde, 2014, Paris, Éditions Nathan, 17. Moreover, in the Northern region, both French and Bambara were seen as oppressive (colonialism, post-colonial authoritative regime), see Dia, Fatoumata (2011), «Le mariage interlinguistique au Mali: Étude du cas de Bamako en 1987 et en 1998,» MA dissertation, Université Laval.

${ }^{24}$ Especially with regards to the smuggling of cannabis coming from the Rif Valley, in which the Moroccan authorities are, to some degree, involved. See UNODC, Rapport mondial sur les drogues: résumé analytique 2009, p. 24.
} 


\subsection{Encircling the Economic and Social Effects: State Withdrawal and Security Gap}

The partial implementation of the clauses contained in the different peace agreements led to a withdrawal of the central State from the northern regions. The decentralization promised by the agreements, though badly implemented, led to a demilitarization of the areas and created what could be called a 'security gap.' That was marked by a weak presence of the country's armed and security forces in those areas. At the same time, the peace treaties signed with the rebels demanded the reduction of military presence in the Nomad-led areas. In any case, it was even very difficult for the army to assign security personnel to the region because of its difficult geographic and climatic conditions. The void left by the military and authorities permitted the rebels and religious terrorists to get more power by 'forcing' the other ethnic groups who did not share their politics to either follow them or leave the areas. They played the role of an 'absent state' by collecting taxes, assuring the security of the populations, and providing them medical care, water, and electricity. They also lent a hand to the poor families by getting married with their daughters and provident for their needs and their families'. It was at that time that the different groups organized into movements with a view to defending the interests of the ethnic group they belong to.

The Malian army's withdrawal from the northern regions called 'Azawad' may have reflected the relative prioritization of scarce State resources or calculations that an increased military presence in the North would be destabilizing given the region's history of Tuareg rebellions. It permitted the different terrorists and bandits to occupy the void and transform it in a no man's land, a law-free area and of trafficking of all kinds. Among the businesses that were very rife included drugs, cigarettes and counterfeit products trafficking, illegal migration flows, and exchange of stolen car spare parts were between the Sahelian populations. ${ }^{25}$ This has urged some analysts to posit that a tacit agreement between the central government authorities and AQIM (Al Qaeda in the Islamic Maghreb), under which the government did not vigorously run down AQIM and the latter, in turn, did not directly threaten Bamako. As a result, smuggling, above all of cheap foodstuffs, became closely associated with meeting basic human need, compelling anthropologist Judith Scheele (2009) ${ }^{26}$, reflecting on the significance of prohibited commerce with Algeria, to state that 'in the north of Mali, whoever says trade means fraud. At Kidal or among the Arabs of Gao, people eat Algerian pastry, Algerian couscous [...]. This trade was well organized, in a way that was semi-official and known to everybody." 27

\footnotetext{
${ }^{25}$ A 2009 UN Office on Drug and Crimes report Stated that cigarettes coming from the Far East (China and Vietnam) and Europe (Bulgaria, Luxembourg, Greece) transited through free tax zones (Dubai) and arrived in West Africa before their final destination, North Africa. Due to its geographic position, Mali has become one of the main West African countries through which cigarettes are transiting. In the 1990s, Gao also became a major hub for illegal migrants and a transit area to North Africa and Europe. Finally, drug trafficking became an important part of the Malian criminal economy as hashish and cocaine transited through the North of the country. As an alternative to the traditional route going through Algeria, hashish production from the Moroccan Rif Valley is now transiting through the North of Mauritania and goes East through Northern Mali and Northern Niger. Cocaine also deviated from its traditional route and is now transported from coastal hubs (Mauritania and Guinea) overland to North Mali and on to Maghreb. Over time, other goods such as counterfeit medicines and stolen car parts have also became part of the illicit economy. See UNODC, Rapport mondial sur les drogues: résumé analytique 2009, p. 24.

${ }^{26}$ Scheele Judith (2009), “Tribus, États et Fraude: la Région Frontalière Algéro-Malienne,” Études rurales, June/ December

${ }^{27}$ Scheele Judith (2009), “Tribus, États et Fraude: la Région Frontalière Algéro-Malienne,” Études rurales, June/December, p. 81.
} 
In fact, the Northerners reject the supremacy of the Black Bambara population whom they blame for their marginalization. There also existed animosity that was based on skin color, within the Tuareg group, where dark-skin low-classes populations were under control and even kept in bondage by those with lighter-skin high-class populations. ${ }^{28}$ Therefore, most of the different tensions that emerged in Malian society between different ethnic groups like the Tuareg and Songhay, Fulani and Dogon, sedentary and pastoralists, people from the north and people from the south, White (light-skinned Tuareg or Arabs) and Black, as a result of exclusion and inequalities, were due to the absence of administrators and military forces in the different areas. The situation resulted in the deaths of many citizens and installed mistrust between the established communities. This is evidenced by the reaction of theTuareg and Arab descent respondents, men and women, from both the north and south during an interview. They testified how they had been bullied, harassed, and threatened, because of their lighter skin color, and accused of being responsible for the crisis that broke out in $2012 .{ }^{29} \mathrm{In}$ marrying some Islamist members and thus joining their cause, both impoverished Bellah women and men can improve their social status and economic situation, and seemingly detach themselves from the stigmas attached to their class (Abu Dardar - MUJWA leader, married a Bellah woman). ${ }^{30}$

The situation became more complicated with the civil war in Algeria in 1990 when the Salafist groups were chased from the country after they won the elections. They found refuge in the north. The first hostage takings of 2003 when 32 Europeans were captured by the Salafist Group for Preaching and Combat (GSPC) also contributed in isolating the northern regions and exacerbating the economic crisis. The Dogon country which is located in the region of Mopti suffered a lot from those ongoing conflicts. The locality is known for its important tourist sites such as the cliffs of Badiangara, the hand of Fatima, the Mount Hombori [...]. Tourism was a real industry for the population of the area which flocked by tourists hailing from everywhere in the world. Because of its tourism hub, the area was home to many hotels and restaurants, road networks and transportation systems. Therefore the Dogon people highly depended on tourism for their survival. As the sites were very attractive, the coming of the tourists helped to build schools, hospitals, and supply the localities with school furniture. This industry which had been flourishing for twenty years in Mopti and on the Dogon plateau had then collapsed. Added to that was also the terrorists' threats to destroy all the touristic sites. The motive was that they considered them as places of gathering for apostate and unbelievers. The Western tourists fled the area for fear of kidnapping and executions. $^{31}$

Indeed, tourism activities used to represent more than 80 billion FCFA of income (121 M€, only 1.2 percent of national GDP but one of the main sources of income for the northern regions, where tourism sites are located) and provided jobs for 17,000 people in 2005 . However, more than 8,000 people lost their jobs between 2009 and 2011, and the revenue generated by the sector dropped by 50 billion FCFA (76.2 M€). ${ }^{32}$ The continuous presence in the north of GSPC, whose members swore allegiance to Al Qaeda in the Islamic Maghreb

\footnotetext{
${ }^{28}$ Interviews, Mbera refugee camp, Mauritania, 2015, interviews, Mali, 2015.

${ }^{29}$ Focus group, Mali, 2015.

${ }^{30}$ Interview with a youth association's leader in Gao on September 8, 2017.

31 “Mopti, la Venise du Mali désertée par les touristes," TV5 Monde, 24 octobre 2012.

32 Serge Daniel (August 1, 2011), “Au Mali, le tourisme connait une crise sans précédent," Radio France Internationale.
} 
(AQIM) in 2007, marred all tourist activities in the area. The fact that the terrorists kidnapped tourists particularly the Westerners compelled them to flee the affected regions, thus making life extremely difficult for the local populations whose major incomes were generated from tourist activities, and forcing many youths to join extremist or rebel groups. Many of these young people only sought to find ways and means of coping with socioeconomic marginality, 'social death' and 'security for self and family' rather than with political or religious beliefs.

France and USA-backed MNLA in its quest for independence tied alliances with terrorists and launched violent conflicts on January 17, 2012 to defeat Malian army. The alliances led to imposing a new way of life on the population of these areas by MNLA, Ançar El Dine, and other armed groups. The latter went hand in hand with the Islamist terrorists and imposed a fundamentalist interpretation of Islamic laws based on the Sharia Law. Those who refused to be subject to the new rules and practices or who infringed them were punished by virtue of the Sharia Law. When the armed Islamist groups took power in the northern communities, they enforced their political program and social order, focusing particularly on women's status, functions, and private moral issues. Therefore, women were banned from all public activities, while the freedoms of men, women and youths were limited. Music and television were banned, as well as many other activities like sport that were deemed important to children and youths in modern society. The Sharia Law was rigorously enforced, which resulted in numerous human rights violations with some women forced into seclusion and to wear the veil at all times, even in their own homes, and no public role to play. Their freedom of movement was severely restricted and they would be allowed to leave their homes only if they were veiled and accompanied by a male relative. ${ }^{33}$ Men were in turn assigned strict obligations with regard to proper behaviours and clothing as way of reflecting their righteousness and piety spirit, and determining their social capital. As such, men were subject to rules of modesty, forced to wear shorter trousers, banned from drinking alcohol and smoking cigarettes.

However, the difficult economic condition added to oppression by some religious extremists triggered the mass displacement of populations both internally and to neighboring countries. Since the first rebellions people were forced to leave their homes, fearing the clashes between the Malian army and the rebels, ethnic cleansing as in 1963, 1990, other groups had left the areas where the armed Tuareg groups claimed autonomy, thus engendering a volatile security situation there. Further displacement took place following the occupation of Kidal, Gao, and Timbuktu in 2012. Someof the reasons the displaced groups gave to account for their displacement was their abandonment by the Malian authorities, lack of public services, and fear of imposition of a 'strict version' of the Sharia Law by Islamist occupants, together with fear of international military interventions. The internally displaced people went to live with relatives who lived in other parts of the country, while others crossed into neighboring countries and ended up settling in some refugee camps.

During the latest conflicts and following the abandon and occupation of the main northern cities, girls and women were exposed to rape, domestic violence, sexual exploitation, trafficking, sexual humiliation and mutilation, and acts of revenge. Rapine violence spread throughout town streets and village paths. Sexual violence against women and girls was used as a tool to communicate hostility to the black communities (Bellah, Dogon and Bambara). As such, there were reported cases of women being raped in front of their husbands, children or

\footnotetext{
${ }^{33}$ Benjamin Soares (2013), "Islam in Mali since the 2012 coup" Field sights - Hot Spots, Cultural Anthropology Online, June 10, 201, p. 35.
} 
relatives. When MNLA secessionists and the terrorists occupied the main cities, particularly Askia City and Timbuktu, they abducted girls, some of whom were gang-raped and then dumped without any care. They especially targeted the Bellah women and girls, whom they considered to be their 'slaves.' Many eyewitnesses account reported that the attacks went hand in hand with systematic verbal abuse with racial connotation. As reported by a young girl who was raped, "while they were raping me, they called me a fucking bitch and dirty slave in French." 34 Girls were also forced to marry several rebels before being later gangraped and abandoned after a swift divorce as reported by a victim, saying that "when they married me, every night it was a new man who came and shared the bed with me. When I complained, one of them told me that they had collected money to pay my dowry. I have finally fled." 35

Apart from rape and other forms of sexual violence against women, in Gao for example some women willingly turned themselves into sexual toys in exchange for staple commodities like food, and shelter. The use of sex as a commodity became more visible during the different rebellions and the Islamists' occupation. Some Bellah and Tuareg women were known to give themselves over to combatants who in turn assured their protection against other brutal forces. Other women were persuaded or forced by their families to exchange their bodies for such favors, which in turn benefitted the whole families. ${ }^{36}$ In these conflicts child soldiers, comprising boys and girls under 18 of age, were involved in recruited by both the rebels and militias forces. ${ }^{37}$ They served as combatants, messengers, porters, cooks. They could provide sexual services when needs be. Some were forcibly recruited or kidnapped while others joined in because of poverty, abuse, and discrimination, or for just revenge's sake for the violence inflicted on them or their family member(s).

\subsection{The Challenges towards Reconciliation and Sustainable Peace: Endogenous and Exogenous Solutions}

The government should end divisions between local elites by involving them in the political debate rather than resorting to arms to resolve their differences and rivalries. It is necessary to prevent political competition from leading to the formation of armed militias as the ones present in the north. Moreover, the stigmatization of some nomadic elites because of their recent association with groups such as the Movement for Unity and Jihad in West Africa (MUJWA) was counterproductive in the long term. It is essential to avoid a situation in which some communities, because of their feeling of exclusion, would be tempted to join radicalized groups in order to make their voice heard. In partnership with the government, the local elites can play a central role in acknowledging their part of responsibility for the current turmoil and stop blaming each other and manipulating their desires for vengeance. The government could appoint a high representative for the central regions who would be responsible for the coordination of development initiatives and the preparation of special out-of-crisis development plans.

\footnotetext{
${ }^{34}$ Interview with a rape victim in Gao, September 9, 2017.

${ }^{35}$ Fatoumata Keita (2014), Crise sécuritaire et violences au nord du Mali, La sahélienne, Bamako, p. 55.

${ }^{36}$ Many islamists got married with Bellah in order to get protection from MNLA combatants others to satisfy their daily needs (food, medicines, water...), some Tuareg women also got married with the Southern soldiers for protections, (interview with a Tuareg ).

37 "War crimes in North Mali," AMDH-FIDH report (18 July 2012), op. cit., p. 17.
} 
The peace agreement had disregarded the centre so much that it could not be implemented there effectively. The different sectors of the civil society in this part, not only armed groups or those in power, should be deeply involved in the designation of such plans so as to ensure that the elite will not take the lead. The peace agreement signed in Bamako, which was rather favorable to the armed movements, was not the product of an inclusive process and was contested by the majority of the population both in the south and the north. ${ }^{38}$ Only the Disarmament, Demobilization and Reintegration (DDR) program, which pre-existed it, could be extended to the Malian central part, as expected in the agreement, in order to facilitate disarmament and reduce the increasingly worrying availability of war weapons. Even if the objective of the DDR process, with political, military, security, humanitarian and socio-economic dimensions, aims at contributing to security and stability in post-conflict Mali so that recovery and development can begin in the war-torn areas. Though complex a process, DDR seeks to deal with the post-conflict security problem that arises in Mali when ex-combatants are left without livelihoods or support networks, other than their former comrades, during the vital transition period from conflict to peace and development. Through a process of removing weapons from the hands of combatants, taking the combatants out of military structures and helping them to integrate socially and economically into society, DDR should not be gender-based, it should support male and female ex-combatants and men, boys, women and girls associated with armed forces and groups, so that they can become active participants in the peace process. ${ }^{39}$ It has then to be inclusive so as to avoid divisions and risk of frustrations.

The peace agreement signed in June 2015 in Bamako applies to the Northern regions and contains only few references to the centre. Many public figures who live in this part of the country particularly from the Fulani ethnic group feel that history is repeating itself. They are upset that peace is being built up without their involvement, if not against them, urging even some to state that one needs to take up arms to be heard. Some of them also argue that the armed network that supported Kouffa emerged precisely because there was no local armed group to bring the area into the spotlight. Peace is not something that can be forced or imposed on people, for building peace requires much time; building and sustaining peace is long process and a real challenge. It involves coming to terms with an imperfect reality which requires changes in [our] attitudes (e.g., tolerance instead of revenge), [our] aspirations, emotions, and feelings, perhaps even [our] beliefs. Such profound change is a vast and often painful challenge that cannot be rushed or imposed on. Unlike many other African countries an inter-ethnic harmony used to be the cornerstone of the strength of Malian society and peace.

Moreover, Malians system of democracy and the way they organized their society did not tally with the aspirations of the citizens. The reality was that this form democracy was fragile and shallow. Therefore, the international donors should know that the politics of opposition in USA and France may not be suitable for Mali because traditions and culture here are different. The systems used to exercise popular power should be developed from within. Because democratic systems that are imposed from outside by the seemingly superpowers are mostly likely to fail and generate misunderstanding among the local populations. The inclusion of these facts by international donors and creditors could help to

\footnotetext{
${ }^{38}$ Crisis Group Africa Report N226, Mali: An Imposed Peace?, May 22, 2015.

${ }^{39}$ Ban Ki-Moon, Secretary-General, note to the General Assembly, A/C.5/59/31, May 2005

http://www.unddr.org/what-is-ddr/introduction_1.aspx, Thursday, September 27, 2018.
} 
promote peace and social harmony in Mali. It took the Western world hundreds of years to build what they call 'liberal democracy.' For example, the State-building process in Norway began in the $19^{\text {th }}$ century and universal suffrage was not introduced until 1913. In the USA, the most important issues of national identity and political legitimacy were forged over a century. It took the country fifty years to consolidate a competitive party system while the separation of the State from gross political patronage took also over one hundred years. ${ }^{40}$ One must move away from the 'arrogant assumption' that only the West countries know how to govern and apply democracy, for they cannot be a universal democratic system or democracy, but rather 'democracies.'

An effective decentralization process should lead to a unitary State with regions endowed with an assembly and an executive power. The power of this assembly, its human and financial resources must be defined in the new constitution. As the decentralized power would be elected by the local populations, the legitimacies should be up to the delegated power. The creation of two chambers (houses) with the first symbolizing the country's unity and diversity could be an answer to the secessionists' demand of autonomy. The selection criteria of the elected should be rigorously defined and implemented. The president could remain chief of the executive but with a limited power. The members of the government should be validated by the parliament. Therefore, a real solution to the crisis in the north could speed up the decentralization process, but this time in combination with real local capacity-building in a transparent manner. This could pave the way for an improved locallevel political representation of various political, ethnic, religious, and cultural groups in decision-making processes, and the implementation of development programs for the warstricken inhabitants. The secessionism claim could be taken as a 'negotiating tactic' aimed at pressurizing the central government for more autonomy in managing their region and a strategy to push for an eventual referendum. As MNLA Cabinet member Nina Wallet states in an interview that "we can be economically independent without cutting the territory in two. We want autonomy, with our own government, our own ministers, our own budget," 41 The limits of the decentralization politics should be clearly defined in the Malian constitution along with the roles of the local and State representatives. Since all religions have peace entrenched in their holy books, they should teach and promote the virtues of peace, forgiveness, reconciliation, love, respect for life and other values that promote nonviolent change. In a secular country, members of different faiths are expected to respect one another's opinions and religious beliefs to forge unity and respect.

The international community should not be a group of friend countries that defended only their vested interests instead of promoting peace. Most of the Malian population refers to the international community as France and its European and US allies, which many think come up with a neocolonial and recolonial agenda. As a case in point, despite the high economic and human cost caused by the different conflicts that hit Mali, many stakeholders have sought to profit from them instead of striving to abate the violence. Among those who profited from the inter-Malian conflicts are the European arms industries, international arms merchants, the superpowers that have created disorder to better exploit the country's untapped natural resources or conditioned their help to the government in exchange for markets. The

\footnotetext{
${ }^{40}$ Sorbo Gunnar M. and Vale Peter (1997), Out of Conflict: From War to Peace in Africa, the Nordic Africa institute, Uppsala, Sweden, p. 27.

41 Hannah Armstrong (May 31, 2013), "Crisis in Mali: Root Causes and Long-Term Solutions," PeaceBRIEF149, United States Institute of Peace, p. 3.
} 
Saharan regions of Mali that could not boast of one functioning factory have its streets littered with the latest and sophisticated bombs, guns, grenades, and other weapons of mass destruction capable of a high order of destruction or causing mass casualties and of excluding the means of transporting or propelling the weapon where such means is a separable and divisible part from the weapon.

Sustainable peace should be home-grown because pain, misery, and discrimination can only be known and acknowledged by those who suffered from them and those who caused the injustice. Only the victims and the perpetrators can make peace with one another. The role of the international community should be that of a facilitator, power generator, instead of that of a one that is imposing and 'picking up the fruits of sorrow,' drowning post-conflict societies in a sea of foreign projects (as in Kosovo), and choosing capacity building above importing experts. ${ }^{42}$ Building a sustainable peace should be based on mutual trust and respect between the protagonists. In the different situations of Mali, the international community, ECOWAS, AU, UN should work together to create an impartial justice system. Justice was the domain where the international community was directly involved in processes that had a reconciliation potential. The deathful and brutal conflicts have totally impoverished the country and affected the judiciary system. To an extent that it now lacks the material and technical resources it needs to set up 'legal healing projects,' truth commissions and reparation programs. Strong democracy also needs a well-trained army. Training and supporting Milan army forces is a prerequisite to any democratization process in the country. Democracy rests on a good, discipline, well trained and motivated security force. This should go hand in hand with good working conditions in order to be in a better position to assure the security of people and their goods. The procedures of recruitment in army should be reviewed in order to have powerful and professional one.

\section{Conclusion}

This article has shown that Mali's Tuareg irredentism and military coups have roots in the (neo)colonial politics of divide-and-rule which consists in separating populations and engendering grievances and feelings of rejection, marginalization, and exclusion. This has contributed in paving the way for a fierce competition over trafficking and smuggling (cigarettes and, more recently, migrants and drugs) involving some leaders from the northern part of the country, authorities of Bamako, and Islamist terrorists.

The paper has sought to build up an off-the-beaten track narrative of the ethnoreligious and political conflict in post-colonial Mali. This goes counter the common discourse that attempted at explaining the crises that hit this West African country though the western media such as RFI, France 24 and TV5 that have dramatized the situation by portraying and making the secessionists Tuareg famous martyrs whose welfare should only be in a 'federal State.' Since they had always been described as marginalized people, the 1963 rebellion was described as 'genocide' against the Tuareg ethnic group. The subjective interference of the Western neocolonial media that tends to side with the Tuareg, combined with a radical Islam, and fragmentation of rebel groups, and the internationalization of the conflicts, have highly contributed injeopardizing the rapid resolution of the conflicts. To these one can also add the multiplicity of rebel groups and their lack of true leadership capable of gathering the different

\footnotetext{
${ }^{42}$ Barnes Ann Teresa et al. (2003), Reconciliation after Violent Conflict, Stockholm, Sweden, International IDEA, p. 164.
} 
fractions around. The resolution of an armed conflict with a group and by a group alone has been detriment to the peace process. The sedentary populations, mainly composed of Blacks (Bambara, Bellah, Bozo, Dogon, Fulani, and Songhay), had taken their guns because they has felt being marginalized and forgotten (Ganda koy, GandaIso). The authorities should then adopt a real integration program that targets all Malian citizens without distinction of political obedience, gender, race, ethnic and religion.

The DDR is also a very good and sustainable peacekeeping mechanism that lays the groundwork for safeguarding and sustaining the communities in which Maliansreturn, while building national capacity for long-term peace, security and development. Therefore, it is essential to note that DDR alone cannot resolve conflict, prevent violence, or enable development. It can, however, help establish a secure environment so that other elements of a recovery and peace building strategy can proceed. To make it effective, history has taught [us] that, despite the multiple peace agreements signed between/among war stakeholders, peace still remains fragile and is subject to setbacks if the parties' commitments are perceived to be inadequate or if the implementation of peace accords is delayed. Achieving sustainable peace is thus more complex than any other task that the Malian governments have undertaken so far, hence the need to reset society's direction and design new (alter)natives means for the country in the political, economic, and socio-cultural fields.

\section{References}

Achebe Chinua (1964), Arrow of God, Heinemann, UK.

Achebe Chinua (1966), A Man of the People, London, Heinemann,.

AMDH-FIDH report "War crimes in North Mali," (18 July 2012).

Armstrong Hannah (2013), "Crisis in Mali: Root Causes and Long-Term Solutions," PeaceBRIEF149, United States Institute of Peace.

Burdeau Georges (1980), «L'Etat», in Traité de Science Politique, Paris, LGDJ.

Chauzal Gregory \& Damme Thibault van (2015), The Roots of Mali's Conflicts: Moving Beyond the 2012 Crisis, CRU Report, Clingendal.

Crisis Group Africa Report N²26, Mali: An Imposed Peace?, May 22, 2015.

Daniel Serge (2014), Les Mafias au Mali: Trafic et terrorisme au Sahel, Paris, Descartes et Cie.

Daniel Serge (2011), "Au Mali, le tourisme connait une crise sans précédent," Radio France Internationale.

First Ruth (1970), The Barrel of a Gun: Political Power in Africa and the Coup d'Etat, London, Penguin.

Focus group, Mali, 2015.

Gremont Charles (2010), Touaregs et Arabes dans les forces armées coloniales et maliennes: Une histoire en trempe d'ail, Paris, IFRI Programme Afrique Sub-Saharienne.

Gunnar M. Sorbo and Peter Vale (1997), Out of Conflict: From War to Peace in Africa, the Nordic Africa institute, Uppsala, Sweden.

Hodgkin Thomas \& Morgenthau Ruth Schacter (1964). "Mali". In James Scott Coleman (ed).

Political Parties and National Integration in Tropical Africa. Berkley, CA: University of California Press, 216-258.

Interview with a rape victim in Gao, September 9, 2017. 
Interview with a youth association's leader in Gao on September 8, 2017.

Interviews, Mbera refugee camp, Mauritania, 2015, interviews, Mali, 2015.

Judith Scheele (2009), "Tribus, États et Fraude: la Région Frontalière Algéro-Malienne," Études rurales, June/December

Juma Monica (2006), Compendium of Key Document Relating to Peace and Security in Africa, South Africa, Pretoria University Law Press (PULP) .

Keita Fatoumata (2014), Crise sécuritaire et violences au nord du Mali, La sahélienne, Bamako.

Ki-Moon Ban, Secretary-General, note to the General Assembly, A/C.5/59/31, May 2005

http://www.unddr.org/what-is-ddr/introduction_1.aspx, Thursday, September 27, 2018.

Konate Moussa (1990), Mali Ils ont assassiné l'espoir, Paris, L'Harmattan.

Lee Robert (1970), Orwell's Fiction, Notre Dame, IN: University of Notre Dame Press.

Maïga Mohamed Tiessa-Farma (1997), Le Mali: De la sècheresse a la rébellion nomade. Chronique et analyse d'un double phénomène du contre développement en Afrique sahélienne, Paris, France, L'Harmattan, 104-105.

Péan Pierre (1988), L'Argent Noir: Corruption et sous-développement, Paris, Fayard, 232233.

Poulton Robin-Edward andYoussouf Ibrahima ag (1998), A Peace of Timbuktu: Democratic Governance, Development and African Peacemaking, Geneva, UNIDIR.

RFI, Mémoire d'un continent, recorded in Bamako in October 1988.

Soares Benjamin (2013), "Islam in Mali since the 2012 coup" Field sights - Hot Spots, Cultural Anthropology Online, June 10, 2012.

Teresa Barnes Ann et al. (2003), Reconciliation after Violent Conflict,Stockholm, Sweden, International IDEA.

TV5 Monde, “Mopti, la Venise du Mali désertée par les touristes,” 24 October 2012. 